\title{
Growth characteristics of Thiobacterium sp. from the plume of hydrothermal vents of the North Fiji Basin
}

\author{
Humitake Seki, Takeshi Naganuma* \\ Institute of Biological Sciences, University of Tsukuba, Tsukuba, Ibaraki 305, Japan
}

\begin{abstract}
A chemosynthetic bacterium of the genus Thiobacterium was isolated from the plume of hydrothermal vents of the North Fiji Basin. The bacterium occurred singly as rods mostly sized 0.2 by $1.0 \mu \mathrm{m}$, and having a population growth rate varying between 0.025 and $0.1 \mathrm{~h}^{-1}$ during the lag phase of its growth cycle. During exponential growth, cells occurred singly and in short chains as larger rods of 0.5 by $1.5 \mu \mathrm{m}$ with a population growth rate from 0.1 to $0.5 \mathrm{~h}^{-1}$. When bacterial growth reached stationary phase, the majority of cells occurred in chains which were extensively branched and embedded in a gelatinous material. In the late stationary phase, branching cells constructed a network structure to grow finally into a bladder-like colony. Population growth rates during the early stationary growth phase were again 0.025 to $0.1 \mathrm{~h}^{-1}$. During the death phase, when population growth rates were from -0.6 to $0.025 \mathrm{~h}^{-1}$, the chains and colonies of bacterial cells broke up into single cells.
\end{abstract}

During an oceanographic survey in 1987 (Auzende \& Honza 1988, Honza \& Auzende 1988), an abundant population of chemosynthetic bacteria was enumerated by the method of viable counts in the plume of hydrothermal vents at the spreading center of the rift system of the North Fiji Basin. The bacteria were predominantly in the plume rather than in the layers immediately above the plume (Naganuma et al. in press). Hence it appears that these chemosynthetic bacteria were dependent on the energy sources of reduced chemicals issuing from the hydrothermal vents.

A Thiobacterium species has never been isolated before from hydrothermal vents of other rift systems, but it was isolated in 1987 as one of the dominant chemolithotrophic bacteria from water within the plume of hydrothermal vents in the North Fiji Basin. Its growth characteristics were examined experimentally to clarify its ecological role in the hydrothermal vent community.

Materials and methods. Microbiological samples

\footnotetext{
- Present address: Japan Marine Science and Technology Center, Natsushima 2-15, Yokosuka, Kanagawa 237, Japan
}

(C) Inter-Research/Printed in F. R. Germany were collected with sterilized Niskin microbiological samplers (General Oceanics Inc, Florida) from $2671 \mathrm{~m}$ at a site $\left(17^{\circ} 44.40^{\prime} \mathrm{S}, 173^{\circ} 39.87^{\prime} \mathrm{E}\right)$ in the North Fiji Basin characterized by hydrothermal vents. The Niskin sampler was attached to a CTD (Sea-Bird Electronics Inc., Washington) Rosette (General Oceanics Inc., Florida) sampler in order to collect the sample exactly from the desired site. The water sample was enriched with TB Medium (Tuttle \& Jannasch 1972) for isolation of chemolithotrophic bacteria. The medium has the following composition: $\mathrm{Na}_{2} \mathrm{~S}_{2} \mathrm{O}_{3} \cdot 5 \mathrm{H}_{2} \mathrm{O}, 10 \mathrm{~g}_{i} \mathrm{~K}_{2} \mathrm{HPO}_{4}$ $0.25 \mathrm{~g} ; \quad \mathrm{KH}_{2} \mathrm{PO}_{4} \quad 0.25 \mathrm{~g} ; \mathrm{NH}_{4} \mathrm{Cl} \quad 0.5 \mathrm{~g} ; \quad \mathrm{MgSO}_{4} \cdot 7 \mathrm{H}_{2} \mathrm{O}$ $0.25 \mathrm{~g}$; filtered seawater $1 \mathrm{l}$; $\mathrm{pH} 7.4$. The isolated bacterial strain was purified on a $1.5 \%$ agar plate of $\mathrm{TB}$ Medium (Collins 1964).

The morphology of the Thiobacterium cells was examined with reference to its FDC (frequency of dividing cells; Hagström et al. 1979) at different growth phases in a batch culture, as FDC has been suggested as an indirect measure of the growth rate of an aquatic bacterial community. The population growth rate was then determined for each FDC value with the appropriate dilution rate in a chemostat (Aiba et al. 1965). By combining these 2 results, the growth cycle of the Thiobacterium strain could be characterized as a combination of the morphology and the population growth rate at a certain FDC value. This bacterial strain was cultured both in a batch culture and a chemostat using a medium of filtered seawater enriched with a final concentration of $1 \% \mathrm{Na}_{2} \mathrm{~S}_{2} \mathrm{O}_{3} \cdot 5 \mathrm{H}_{2} \mathrm{O}$. Seawater used for the medium was collected from the Strait of Georgia, British Columbia, Canada (Table 1). The medium was autoclaved before the chemostat culture was commenced. The chemostat culture was performed at different dilution rates from 0.097 to $0.240 \mathrm{~h}^{-1}$, with intervals of $0.005 \mathrm{~h}^{-1}$ at $16^{\circ} \mathrm{C}$ under normal atmospheric pressure. This permitted the bacterial strain to be examined at different phases of its growth cycle. 
Table 1. Chemical components of the seawater used for chemostat culture. Physicochemical analyses of the seawater was made by the methods in Strickland \& Parsons (1968)

\begin{tabular}{|lc|}
\hline Salinity & $27.790 \%$ \\
$\mathrm{pH}$ & 7.5 \\
Dissolved organic carbon & $0.25 \mathrm{mg} \mathrm{C} \mathrm{I}$ \\
$\mathrm{PO}_{4}$ & $1.5 \mu \mathrm{M}$ \\
$\mathrm{NO}_{3}$ & $46.0 \mu \mathrm{M}$ \\
\hline
\end{tabular}

At every 30 min of the chemostat culture, bacterial cells in subsamples of culture solution were fixed by the addition of $37 \%$ neutral formaldehyde to give a sample:preservative ratio of $20: 1$ by volume. The fixed cells were collected on a Nuclepore filter (diameter of $25 \mathrm{~mm}$; pore size of $0.2 \mu \mathrm{m}$ ), stained for 2 min with a few drops of acridine orange solution $(1: 10000$ in $6.6 \mathrm{mM}$ of $\mathrm{pH} 6.6$ phosphate buffer) and suction-dried before the filter was removed from the filtration apparatus. The filters were examined using a Zeiss epifluorescent microscope. The bacterial counts for each subsample required from 500 to 1000 cells in order to obtain accurate results for further statistical analysis. Differential counts were performed for the number of total and dividing cells, in order to determine the population density and frequency of dividing cells (FDC) of Thiobacterium.

Results and discussion. Among the isolated chemolithotrophic bacteria metabolizing sulfur compounds, one bacterial strain was a non-motile rod without a flagellum. The bacterium had intracellular sulfur deposits when cultured with TB Medium, and was identified as a Thiobacterium species (Buchanan \& Gibbons 1974) (Fig. 1). It was shown to be eurythermally mesophilic (Fig. 2) and slightly halophilic (Fig. 3) when examined in a chemostat with TB Medium under aerobic conditions at different temperatures and salinities. Thus the isolated strain is a typical marine bacterium that can grow well in both psychothermal and mesothermal environments.

The life cycle of the Thiobacterium strain is described here. During the lag phase of its growth cycle, bacterial cells occurred singly as short rods, mostly of size 0.2 by $1.0 \mu \mathrm{m}$. Their FCD values were several per cent during this growth phase. The chemostat culture showed that cells with these values have population growth rates between 0.025 and $0.1 \mathrm{~h}^{-1}$. During this growth phase, each cell was not embedded in gelatinous material.

During the exponential phase, the cells occurred singly as larger rods, mostly with a size of 0.5 by $1.5 \mu \mathrm{m}$, and also in short chains during the late exponential phase. FDC values of the bacterial cells in this phase were generally between 7 and $10 \%$, equivalent to population growth rates of 0.1 to $0.5 \mathrm{~h}^{-1}$. Throughout this phase, all cells were embedded in gelatinous material.
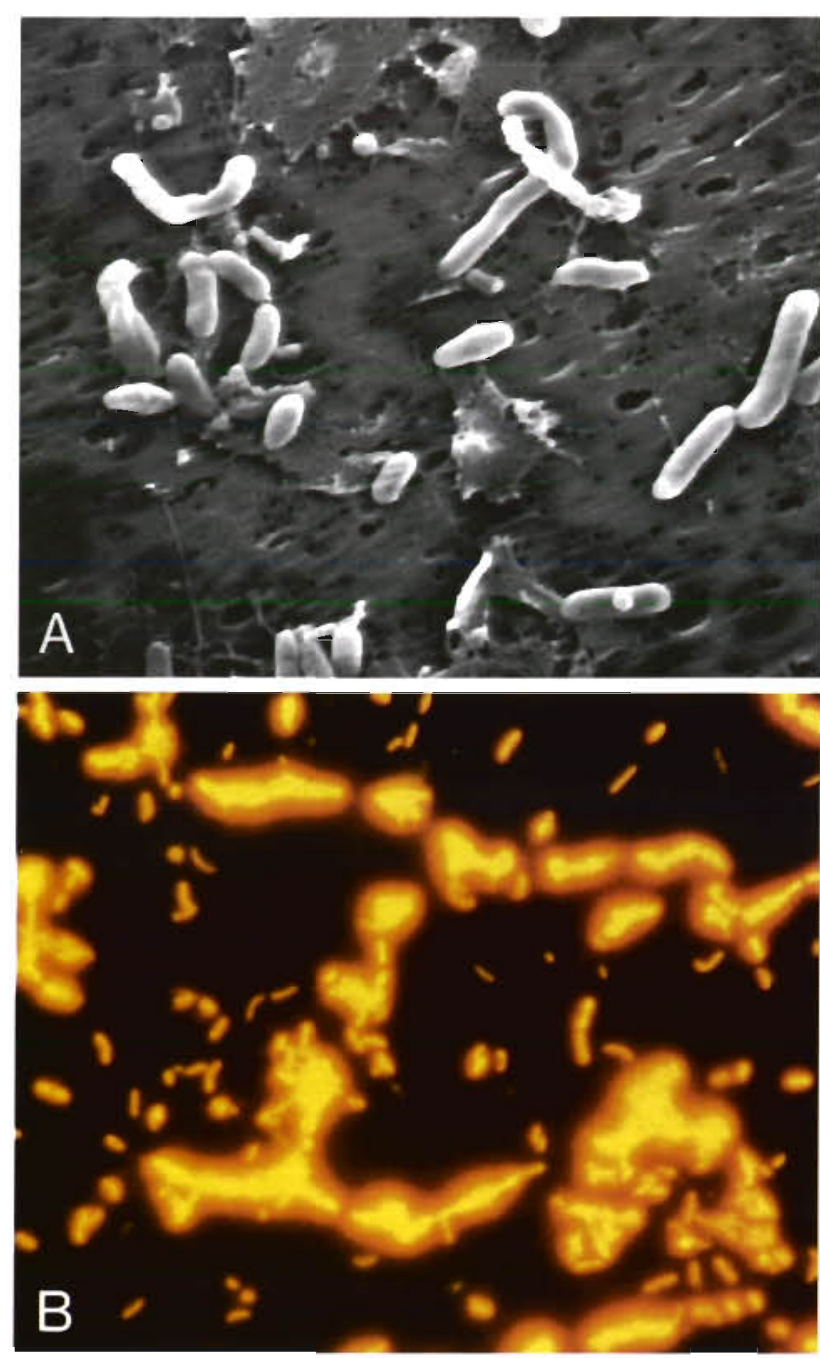

Fig. 1. Thiobacterium sp. Cells of the strain during (A) early exponential phase (electron microscope, $\times 7500$ ), (B) stationary phase (epifluorescent microscope, $\times 1000$ ) of its growth cycle. This chemosynthetic bacterium was isolated by TB Medium at the spreading center of the rift system of the North Fiji Basin in the South Pacific Ocean

During the stationary phase, most cells occurred in chains, and some formed extensive branching structures. These cells were embedded in a gelatinous material. The gelatinous material presumably acts as an energy reservoir and a cell clumping agent during the stationary phase when an energy substrate becomes limiting in the ambient water. In the late stationary phase, branching cells constructed a network structure to grow finally into a bladder-like colony, which included detrital particles. Some of these bladder-like colonies enlarged up to a few $\mathrm{mm}$, possibly due to the adhesive nature of gelatinous material on the bacterial cells. Counts of cells in large bladderlike colonies are underestimates because of uncountable cells inside the colonies. Population growth rates 


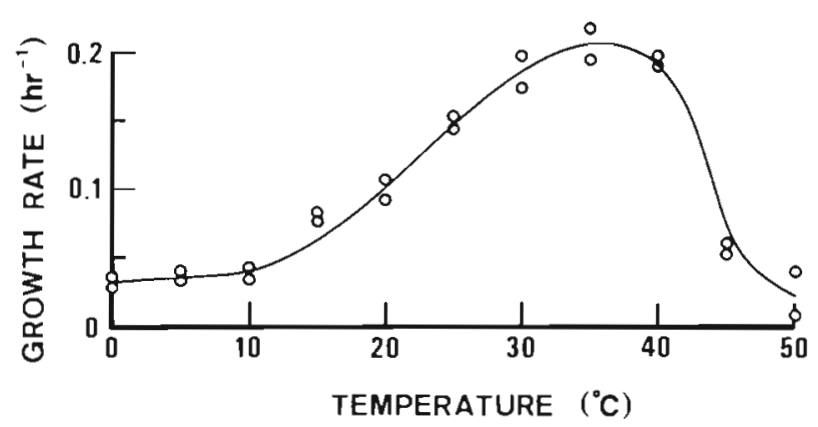

Fig. 2. Thiobacterium sp. Thermal characteristic of the strain as determined from chemostat experiments at salinity $28 \%$

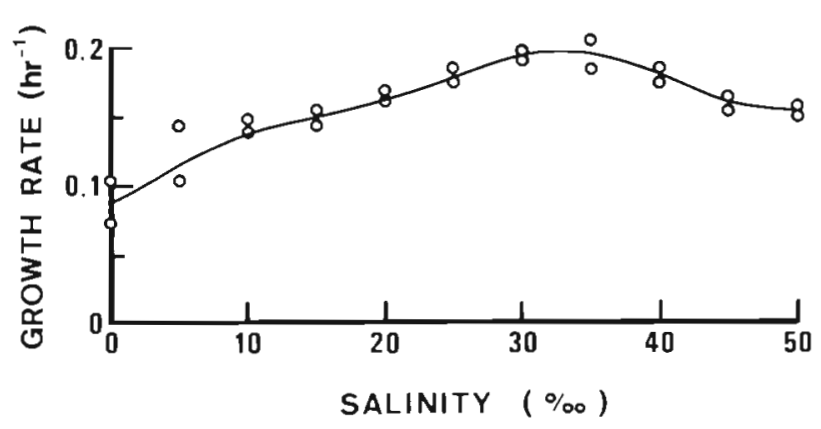

Fig. 3. Thiobacterium sp. Halophilism of the strain at an incubation temperature of $16^{\circ} \mathrm{C}$, measured with different $\mathrm{NaCl}$ concentrations in TB Medium

were estimated only from chemostat cultures without large bladder-like colonies. FDC values of the bacterial cells during the early stationary phase were about $7 \%$, which is equivalent to a growth rate of between 0.025 and $0.1 \mathrm{~h}^{-1}$.

During the death phase, the bladder-like bacterial colonies, as well as most chains, disintegrated into single cells. These bacterial cells had FDC values between 2 and $4 \%$, and the determined population growth rates varied between -0.06 and $0.025 \mathrm{~h}^{-1}$.

Because the maximum growth rate of Thiobacterium cells under chemostat conditions was from 0.1 to 0.5 $\mathrm{h}^{-1}$, its generation time is as fast as a few hours during the exponential phase. When the thermal spectrum of its growth (Fig . 2) and the general hydrostatic effect on bacteria at hydrothermal vent sites (Jannasch 1984) are considered, its in situ generation time must have been about $10 \mathrm{~h}$ under optimal energy supply conditions. As the plume condition is analogous to a kind of chemostat with a constant supply of chemical energy from the vents, chemosynthetic bacteria inhabiting the turbulent plume must be exposed to good nutritional conditions supporting active primary production. The thiosulfate requirement for optimal growth is in the range $10^{-2}$ to $10^{2} \mathrm{mM}$ under laboratory conditions.

The relationship between FDC and growth rate of the Thiobacterium could be expressed by the least squares estimate as a statistically significant line:

$$
\mathrm{Y}=6.69 X+5.16\left(F=13.54, F_{0.01(1 \cdot 27)}=7.68\right)
$$

where $Y=\operatorname{FDC}(\%)$ and $X=$ population growth rate of the Thiobacterium strain $\left(h^{-1}\right)$. This relation was obtained from the experimental data during all population growth phases. This means that FDC values during the stationary and death phases could not be precisely measured; i. e. during these population growth phases, most individual bacterial cells in the large bacterial colonies are found at the zero or minus growth rates, but many single cells are still growing. When one refers only to the relation based on single cells, FDC values at the growth rates of zero and the maximum are about 2 and 8, respectively. Very high FDC values during the late stationary phase are due to unusually high division rates of single cells, stimulated possibly by the excreted organic materials from the autolyzing bacterial cells inside large colonies.

The characteristic of Thiobacterium forming larger particles in the late stationary phase makes them available to filter-feeding organisms in the unique hydrothermal vent community of the deep-sea environment (e.g. Ryan 1984). Larger particles of organic matter have been shown to be more readily filtered. Thus their presence may maintain densities of filter feeders at concentrations higher than when the same prey density occurs only as small particles (e.g. Parsons \& Seki 1970, Parsons \& LeBrasseur 1970). Also, larger particles precipitate onto the ocean floor more rapidly according to the Stokes' theorem (Sverdrup et al. 1942), and can thus be available as food for filter-feeding benthic animals near the hydrothermal vents (e.g. Duursma 1961, Seki 1982).

Acknowledgements. This research was conducted as part of 'The Joint Research Program on the Rift System in the Pacific Ocean' funded by the Science and Technology Agency of Japan (STA) and Institut. Français de Recherche pour l'Exploitation de la Mer of France (IFREMER). This study was performed through the Special Coordination fund of the Science and Technology Agency of the Japanese Covernment. A major part of the chemostat work was conducted at the University of British Columbia with the generous assistance of the laboratory staff of Professors T. R. Parsons and P. J. Harrison.

\section{LITERATURE CITED}

Aiba, S., Humphrey, A., Millis, N.F. (1965). Biochemical engineering. Academic Press, New York

Auzende, J., Honza, E. (co-chefs de mission) (1988). L'accretion recente dans le Bassin Nord-Fidjien: premiers resultats de la campagne franco-japonaise Kaiyo 87. C.r. hebd. Séanc. Acad. Sci., Paris 306: 971-978

Buchanan, R. E., Gibbons, N. E. (eds.) (1974). Bergey's manual of determinative bacteriology, 8th edn. The Williams \& Wilkins Co., Baltimore 
Collins, C. H. (1964). Microbiological methods. Butterworths, London

Duursma, E. K. (1961). Dissolved organic carbon, nitrogen and phosphorus in the sea. Neth. J. Sea Res. 1: 1-147

Hagström, A., Larsson, U., Horstedt, P., Normark, S. (1979). Frequency of dividing cells, a new approach to the determination of bacterial growth rates in aquatic environments. Appl. environ. Microbiol. 37: 805-812

Honza, E., Auzende, J. (eds.) (1988). Starmer Japan-France Project. Kaiyo 87 photographs of the lift system in the North Fiji Basin. Institute of Future Technology, Tokyo (English, French and Japanese)

Jannasch, H. W. (1984). Microbes in the oceanic environment. In: Kelly, D. P., Carr, N. G. (eds.) The microbe 1984. Cambridge University Press, Cambridge, p. 97-1220

Naganuma, T., Otsuki, A., Seki, H. (in press). Abundance and growth rate of bacterioplankton community in hydrothermal vent plumes of the North Fiji Basin. Deep-Sea Res.

Parsons, T. R., LeBrasseur, R. J. (1970). The availability of food

This note was presented by Professor T.R. Parsons,

Vancouver, B. C., Canada to different trophic levels in the marine food chain. In: Steele, J.H. (ed.) Marine food chains. Oliver \& Boyd, Edinburgh, p. 325-343

Parsons, T. R., Seki, H. (1970). Importance and general implications of organic matter in aquatic environments. In: Hood, D. W. (ed.) Organic matter in natural waters. University of Alaska, Fairbanks, p. 1-27

Ryan, P. R. (ed.) (1984). Deep-sea hot springs and cold seeps. Oceanus 27: 1-100

Seki, H. (1982). Organic materials in aquatic ecosystems. CRC Press Inc., Boca Raton

Strickland, J. D. H., Parsons, T. R. (1968). A practical handbook of seawater analysis. Bull. Fish. Res. Bd Can. 167: 1-311

Sverdrup, H. U., Johnson, M. W., Fleming, R. H. (1942). The oceans. Their physics, chemistry, and general biology. Prentice-Hall Inc., Englewood Cliffs

Tuttle, J. H., Jannasch, H.W. (1972). Occurrence and types of Thiobacillus-like bacteria in the sea. Limnol. Oceanogr. 17: $532-543$

Manuscript first received: November 10, 1988

Revised version accepted: March 6, 1989 